\title{
MIR141 wt Allele
}

National Cancer Institute

\section{Source}

National Cancer Institute. MIR141 wt Allele. NCI Thesaurus. Code C82094.

Human MIR141 wild-type allele is located in the vicinity of 12p13.31 and is 94 bases in length. This allele, which encodes MIR141 pre-miRNA, plays a role in the regulation of gene expression. Alteration in the expression of this gene is associated with the development of breast cancer and cholangiocarcinoma. 